\title{
Afgan Talibanı: Dünü, Bugünü ve Yarını
}

\author{
Göktuğ Sönmez ${ }^{1}$ (iD) Gökhan Bozbaş² (iD) Serhat Konuşul ${ }^{3}$ \\ ${ }^{1}$ Dr. Öğr. Üyesi, Necmettin Erbakan Üniversitesi, Siyasal Bilgiler Fakültesi, Uluslararası İlişkiler, Konya, goktugsonmez@gmail.com \\ (Sorumlu Yazar/Corresponding Author) \\ ${ }^{2}$ Doç.Dr., Necmettin Erbakan Üniversitesi Siyasal Bilgiler Fakültesi, Uluslararası İlişkiler, Konya, gbozbas@erbakan.edu.tr \\ ${ }^{3}$ Necmettin Erbakan Üniversitesi, Siyasal Bilgiler Fakültesi, Uluslararası İlişkiler, Konya, serhat.konusul@gmail.com
}

\begin{tabular}{|c|c|}
\hline Makale Bilgileri & ÖZ \\
\hline $\begin{array}{l}\text { Anahtar Kelimeler: } \\
\text { Barış antlaşmas1, } \\
\text { Taliban, } \\
\text { Terörizm }\end{array}$ & 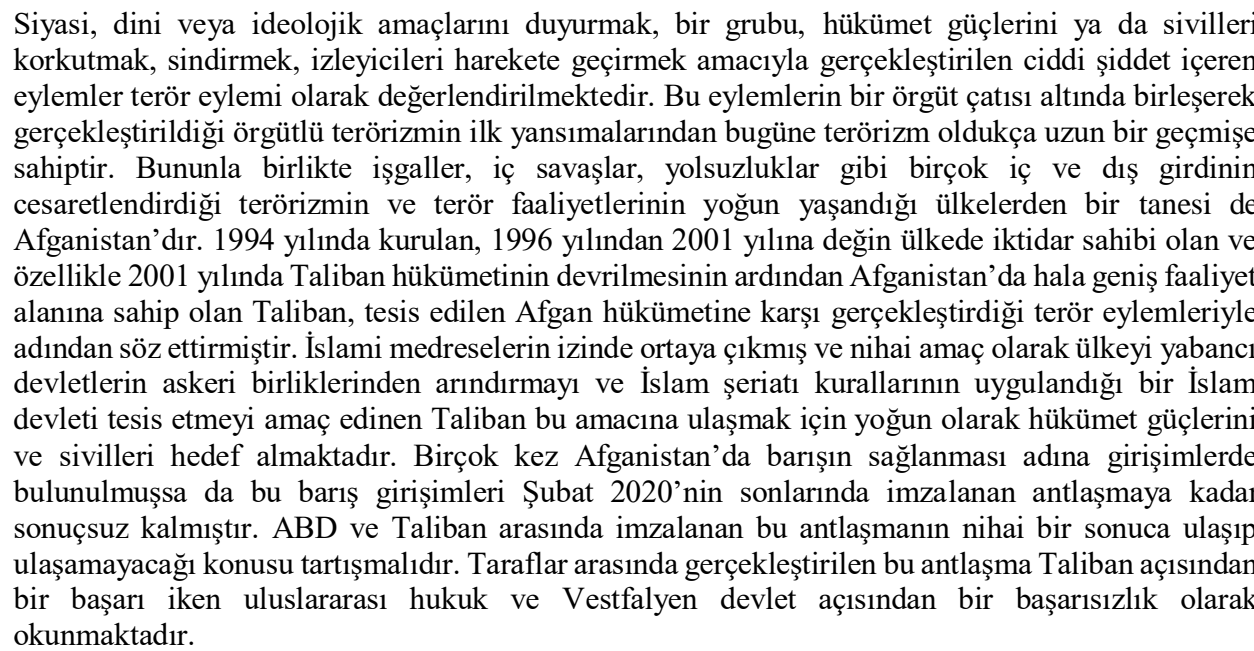 \\
\hline
\end{tabular}

Afghan Taliban: Past, Present and Future

\begin{tabular}{ll}
\hline Article Info & ABSTRACT \\
\hline Article History & $\begin{array}{l}\text { Actions involving serious violence to announce their political, religious or ideological aims, to } \\
\text { intimidate or intimidate a group, government forces or civilians, and to activate the audience are } \\
\text { considered as terrorist acts. Terrorism has a long history since the first reflections of organized }\end{array}$ \\
$\begin{array}{l}\text { Accepted: } 23.11 .2020 \\
\text { Published: } 27.12 .2020\end{array}$ & $\begin{array}{l}\text { terrorism, where these actions were carried out by uniting under the roof of an organization. } \\
\text { However, Afghanistan is one of the countries where terrorism and terrorist activities, which are } \\
\text { encouraged by many internal and external inputs such as invasions, civil wars, and corruption, are } \\
\text { Keywords: }\end{array}$ \\
$\begin{array}{l}\text { intense. The Taliban, which was founded in 1994, held power in the country from 1996 to 2001 and } \\
\text { still has a wide range of activities in Afghanistan, especially after the overthrow of the Taliban } \\
\text { government in 2001, had made a name for itself with the terrorist acts it carried out against the } \\
\text { Taliban, } \\
\text { Terrorism }\end{array}$ & $\begin{array}{l}\text { established Afghan government. The Taliban, which emerged in the footsteps of Islamic madrasahs } \\
\text { and aims to cleanse the country from the military troops of foreign states and to establish an Islamic } \\
\text { state where Islamic Sharia rules are applied, the Taliban intensely targets government forces and } \\
\text { civilians to achieve this goal. Although attempts were made to establish peace in Afghanistan many } \\
\text { times, these peace initiatives remained inconclusive until the treaty signed in late February 2020. It } \\
\text { is controversial whether this agreement between the USA and the Taliban will reach a final result. } \\
\text { While this agreement between the parties was a success for the Taliban, it was read as a failure for } \\
\text { international law and the Westphalian state. }\end{array}$ \\
\end{tabular}

Atıf/Citation: Sönmez, G., Bozbaş G. ve Konuşul, S. (2020). Afgan Talibanı: Dünü, Bugünü ve Yarını, Necmettin Erbakan Üniversitesi Siyasal Bilgiler Fakültesi Dergisi, 2(2), 59-77. 


\section{GíRiş}

Terörizm ve terör eylemleri yalnızca günümüze ait bir sorun olmanın ötesinde tarihsel kökeni derinlere dayanan bir olgudur. Tarihte örgütlü terörizmin ilk örnekleri Ortadoğu topraklarında, Filistin'de I. yüzyılda kendisini göstermiştir. Yazılı metinlerine sınırlı da olsa sahip olunan ve Romalılara karşı sistematik terör taktikleri uygulamış Yahudi Zelot tarikatı -ki bu tarikatın mücadeleleri Flavius Josephus (37-100) tarafindan Romalılarca yaygın bir şekilde kullanılan sicarius -hançerle öldüren- kelimesinden gelen Sicarii terimiyle kaleme alınmıştır- ilk terör örgütlerinden birisi olarak kabul edilmektedir (Chaliand \& Blin, 2016). Terörist örgütün iki klasik örneği olarak kabul edilen Zelot tarikatı ve Haşhaşiler tarikatından, günümüze değin isminden oldukça fazla söz ettiren Japon Kızıl Ordusu, Aum Şinrikyo, Bask Yurdu ve Özgürlük (ETA), İrlanda Cumhuriyet Ordusu (İRA), El Kaide, Halk Savunma Birlikleri (YPG), Irak Şam İslam Devleti (IŞID), Boko Haram ve Taliban gibi örgütlerin varlığı, farklı tarihlerde ve dünyanın farklı yerlerinde terörizm olgusuyla karşı karşıya kalınabileceğinin göstergesi olmuştur.

$\mathrm{Bu}$ çalışmanın konusunu Ortadoğu genelinde Afganistan özelinde Afgan Talibanı oluşturmaktadır. Çalışma konusu olarak Afgan Talibanı'nın seçilmiş olmasının altında birçok sebep bulunmaktadır. İlk olarak, Afgan Talibanı'nın Rusya, Türkiye gibi devletlerce terör örgütü olarak tanınmasına karşın ABD hükümeti NATO, BM ve AB tarafindan Taliban -Afgan Talibanı- herhangi bir şekilde terörist grup olarak kategorileştirilmemiş ve sınıflandırmaya tabi tutulmamıştır. -yalnızca silahlı asiler şeklinde bir tanımlama mevcuttur- ABD'nin böyle bir tutum sergilemesinin altında örgütle masaya oturma ihtimalini kaybetmek istememesi düşünülebilir. Öyle ki 2020 yılı şubat ayında ABD ve Taliban arasında uzun bir sürecin ardından Afganistan'a barışı getirme antlaşması imzalanmıştır. Bu antlaşma birçok devlet ve kurum tarafindan terör örgütü olarak kabul edilen Afgan Talibanı için bir başarı iken; uluslararası hukuk ve Vestfalyen anlamdaki devlet açısından da bir başarısızlık göstergesidir. Taliban özelinde bir çalışma gerçekleştirilmiş olmasının önemli bir diğer sebebi ise Institute for Economics and Peace (IEP) tarafindan y1llı olarak yayınlanan Global Terrorism Index (GTI) 2019 raporlarına göre 2004 yılından itibaren dünyada terörden en çok etkilenen 10 ülke içerisinde birinci sırada yer alan Irak, IŞİD'in mağlup edilmesini takiben ikinci sıraya gerilemiş ve 2015 yılından 2018 yılına kadar ikinci sırada yer alan Afganistan birinci sıraya yükselmiştir (Global Terrorism Index 2019 Measuring The Impact of Terrorism, 2019). 2018 yılı içerisinde gerçekleştirilen ölü sayısının en çok olduğu 20 terör saldırısının, 16 tanesinin Afganistan topraklarında yer alması da konunun seçilmesinde rol oynamıştır. (Global Terrorism Index 2019 Measuring The Impact of Terrorism, 2019, s. 10) Ayrıca GTI 2019 raporlarına göre 2017-2018 yılları içerisinde terör seviyesinin zirve yaptığı iki ülkeden bir tanesi de Afganistan; bir diğeri ise Nijerya'dır. Bununla birlikte terör eylemlerinin Afganistan ekonomisine maliyeti ise Gayri Safi Yurtiçi Hasıla (GSYH)' nin \%19,4'lük kısmına tekabül etmektedir (Global Terrorism Index 2019 Measuring The Impact of Terrorism, 2019, s. 29). Bu durum da aynı raporlara göre Afganistan'ı terörün ekonomideki etkisi sıralamasında zirveye taşımaktadır. Afganistan'da gerçekleştirilen terör saldırılarının sorumluları açık ara Taliban iken bir diğer örgüt ise IŞİD' e biatlı Horasan Vilayeti yapılanması olmuştur (Global Terrorism Index 2019 Measuring The Impact of Terrorism, 2019, s. 19). Kaldı ki Rusya ve Taliban'ın koordineli bir şekilde çalışarak IŞiD' in Afganistan'da güç elde edişini önleme çabalarına da çalışma bünyesinde değinilmiştir. Taliban, Afganistan içerisinde 1994'te gerçekleştirmiş olduğu ilk eylemden bu yana 1996-2001 yıllarında ülke üzerinde kontrolü ele geçirmiş. Daha sonra $\mathrm{ABD}$ ve koalisyon güçlerinin işgali neticesinde kaçmak zorunda kalmış ve daha sonra tekrar güç kazanmaya başlamıştır. ABD ve Taliban arasında 29 Şubat 2020 tarihinde gerçekleştirilen antlaşma da günümüze geldikçe Taliban'ın ne denli büyük bir iktidar alanı sağladığının kabul gördüğ̈nün göstergelerinden bir tanesidir (ABD, Taliban'la imzaladığı anlaşma kapsamında Afganistan'daki askerlerini çekmeye başladı., 2020). Ancak gerçekleştirilen bu antlaşmanın 
nihai kertede Afgan halkının lehine olacağı ve Afgan Talibanı'nın ülkedeki terör eylemlerini azaltacağı hususu tartışmalıdır. Çalışmanın üzerine inşa edildiği soru da burada temellenmektedir. Çatışmanın çözümü için imzalanan antlaşmaya değin Taliban'ın ortaya koydukları, antlaşma sonrası döneme nasıl tesir edecektir?

$\mathrm{Bu}$ çerçevede çalışma içerisinde izlenecek güzergahta öncelikle farklı devlet ve kurumların terörizm kavramını nasıl ele aldıkları belirtilecektir. Buradaki amaç 'terör' kavramının müşterek bir tanımının olmamasının, devletlerce ve kurumlarca farklı şekillerde ele alınmasının terörizmle mücadelede uluslararası iş birliğini zorlaştırması ve devletlerarası ikili ilişkilerini olumsuz yönde etkileyebileceğinin altının çizilmesi hususunda önemlidir. Ayrıca her ne kadar bir devlet genel bir terörizm kavramı ortaya koysa bile zaman zaman ABD'nin Talibanı kategorileştirmesi örneğinde görüldüğü gibi kimi örgütleri bu tanımlamaya dahil edememektedir. Terörizm kavramının ele Tüm bu taslak çizildikten sonra Afganistan'da Afgan Talibanı terörünü ortaya çıkartan sosyo-politik yapıya değinilecek ve sosyo-politik yapının etkisiyle ortaya çıkan terör örgütü -Taliban- ve örgüt yapısı (kaynakları, liderleri), stratejileri (örgütün ideolojisi, hedefleri, politik hareketleri, hedef ve taktikleri, saldırıları), ele alınacaktır. En nihayetinde de çatışma çözümüne ilişkin $\mathrm{ABD}$ ve Taliban arasında imzalanan Afganistan'a barışı getirme antlaşmasının Afgan Talibanı, Afgan halkı ve uluslararası tehdit üzerindeki olası sonuçları tartışılacaktır.

\section{TERÖRIZM KAVRAMI}

Terörizm kavramı, Latince "bilinmeyen ve öngörülmeyen bir tehlike karşısında duyulan aşırı korku ve endişe, dehşet" anlamında kullanılan terror kelimesinden kök almaktadır (Öktem, 2004). Fransız ihtilali akabinde ortaya çıkan 1793 Ulusal Konvansiyon döneminde Jakoben ${ }^{1}$ yönetimi tarafından sistematik bir biçimde uygulanan ve ilan edilen Reign of Terror, terörizm kavramının siyaset ve hukuk alanlarında da literatüre eklenmesini beraberinde getirmiştir. 19. yüzyıl süresince yaşanan gelişmeler neticesinde terörizm, yalnızca devlet eliyle halka uygulanan şiddeti değil, bireyler ya da siyasi gruplarca devlete yönelik uygulanan şiddeti de ifade edecek şekilde evirilmiştir (Öktem, 2004). Literatürde terörizm kavramı henüz oldukça yeni olsa bile giriş bölümünde de belirtildiği gibi ilk örgütlü terör eylemleri Roma dönemi Yahudi Zelot tarikatına kadar dayandırılmaktadır (Chaliand \& Blin, 2016, s. 65). Günümüzde terörizm kavramı araştırmacılar, uzmanlar ve kurumlar tarafından farklı şekillerde ele alınmaktadır. Farklı devletlerin, yapıların ve akademisyenlerin kavram tanımlamalarının farklılı̆g; terörizm kavramıyla her ne kadar sık sık karşılaşılıyor olsa dahi, kavramın daha karmaşık bir anlamı ifade etmesinden kaynaklanmaktadır. Bu kavram ne uluslararası akademik çevrede ne de kanun uygulayıcı kurumlar özelinde üzerinde uzlaşı sağlanabilmiş bir kavram değildir. Bu durum devletlerarası ikili ilişkilerde kimi sorunları da beraberinde getirmektedir. Örneğin; A devletinin B yapısını terör örgütü olarak kabul ediyor olmasına karşın $C$ devletinin $B$ yapısını terör örgütü olarak tanımaması A devleti ve C devleti arasındaki ikili ilişkilerin olumsuz yönlü etkilenmesine sebep olabilmektedir. Ayrıca tanınmış bir terör örgütüyle uzlaşı sağlamak amacıyla bir devletin masaya oturması Vestfalyen anlamda devlet için büyük bir soruna da işaret etmektedir. Diğer taraftan terörizm kavramı yalnızca hükümetler tarafından değil, hükümet içerisindeki ilgili birimler tarafından da farklı şekillerde tanımlanabilmektedir. Bu noktada bazı ülkelerin, ülke içi birimlerinin ve uluslararası yapıların terörizm kavramını nasıl ele aldığına değinmek yerinde olacaktır.

İngiltere, Terrorism Act 2005 raporunda; "Bir siyasi, dini veya ideolojik nedeni ilerletme amacıyla, herhangi bir kişiye veya mülkiyete karşı, ciddi şiddet içeren eylemlerde veya eylem tehdidinde bulunmak" (Martin, 2017, s. 32) şeklinde bir terörizm tanımlamas1 ortaya koymaktadır; bu

\footnotetext{
${ }^{1}$ Fransız Devrimi ertesinde Fransa'ya yaklaşık bir yıl süreyle egemen olan ve devrimden çok daha fazla kanın döküldügü Terör Dönemi'ne sebep olmuş Fransız siyasi partisidir.
} 
tanımlamayla örtüşen Afgan Talibanı uluslararası terör örgütleri listesinde yer almamaktadır. Bunun yanı sıra Taliban'ın bir parçası olan Hakkani Ağı, Taliban'a yardım eden diğer örgütler terör örgütleri listesinde yer almaktadır (Proscribed Terrorist Organisations, 2020). Bu durum terörün nasıl tanımlandığından öte siyasi etkileşimlerle alakalıdır.

ABD Dışişleri Bakanlı̆̆ı, 2003 Küresel Terörizm Örüntüleri raporunda (Patterns of Global Terrorism Report 2003), Amerika Birleşik Devletleri Kanunu 22. Başlığının 2656f (d) Bölümünden alınan tanımda "Terörizm terimi, genellikle bir izleyici kitlesini etkilemeyi amaçlayan, alt grup/grupları veya gizli ajanların belirsiz hedeflerine karşı uygulanan önceden düzenlenmiş, siyasi güdümlü şiddet anlamina gelir." (2656f - Annual country reports on terrorism., 2020) ibaresi yer alırken, Birleşik Devletler Federal Soruşturma Bürosu (FBI) terörizm tanımı “... bir Hükümeti, sivil nüfusu veya nüfusun herhangi bir bölümünü korkutmak veya sindirmek, siyasi veya sosyal amaçların yerine getirilmesini sağlamak için kişi veya mülklere karşı yasadışı güç veya şiddet kullanılması" "2 şeklinde karşımıza çıkmaktadır. ABD tarafindan ortaya konulan bu iki farklı tanım da Taliban'ın terör örgütü listesine dâhil edilmesini gerektirmektedir. Ancak kavram tanımlamaları siyasi etkenler dâhil edildiğinde yetersiz kalmaktadır. Taliban'ın El Kaide gibi uluslararası topluma yönelik saldırılarının olmaması, Taliban örgütü içerisindeki bazı kesimlerin Afgan hükümetiyle barış yapma yönündeki tutumları ve Taliban ile gerçekleştirilecek bir antlaşmaya Taliban'ın taraf olabilmesi gibi parametreler tanımlamaların zorluğunu yahut esnetilebildiğini gözler önüne sermektedir. Bu çerçevede ABD, Talibanı yalnızca silahlı asiler olarak kategorize etmektedir.

Türkiye Cumhuriyeti Terörle Mücadele Kanunu (TMK) çerçevesinde Madde 1- (Değişik birinci fikra: 15/7/2003-4928/20 Md.) terör tanımı, "Terör; cebir ve şiddet kullanarak; baskl, korkutma, yıldırma, sindirme veya tehdit yöntemlerinden biriyle, Anayasada belirtilen Cumhuriyetin niteliklerini, siyasî, hukukî, sosyal, laik, ekonomik düzeni değiştirmek, Devletin ülkesi ve milletiyle bölünmez bütünlüğ̈̈nü bozmak, Türk Devletinin ve Cumhuriyetin varliğın tehlikeye düşürmek, Devlet otoritesini zaafa uğratmak veya yıkmak veya ele geçirmek, temel hak ve hürriyetleri yok etmek, Devletin iç ve dış güvenliğini, kamu düzenini veya genel să̆llğı bozmak amacıyla bir örgüte mensup kişi veya kişiler tarafindan girişilecek her türlü suç teşkil eden eylemlerdir." (7215 TERÖRLE MÜCADELE KANUNU, 1991) şeklinde ortaya konulmuştur. Ancak Türkiye Cumhuriyeti daha şeffaf bir şekilde ve tanımlamalara bağlı kalarak İngiltere ve ABD’nin aksine Afgan Talibanı'nı terör örgütü olarak kategorileştirmektedir.

İngiltere, ABD ve Türkiye'nin yanı sıra Kuzey Atlantik Antlaşması Örgütü (NATO) kavrama ilişkin ilgili olarak, "siyasi, dinî veya ideolojik hedeflere ulaşmak maksadıyla gücün veya şiddetin yasadışı olarak hükümet yahut toplumlara karşı zorlama velveya korkutma gayesiyle, bireylere veya mallarına karşı kullanımı ya da kullanılması tehdididir" şeklinde bir terörizm tanımı ortaya koymaktadır (NATO Glossary of Terms and Definions (English and French), 2019). Ancak ABD ile olan etkileşimi nedeniyle NATO da Afgan Talibanı'nı terör örgütü olarak sınıflandırmamaktadır. Diğer taraftan Birleşmiş Milletler (BM) ise terörizm kavramını, "doğrudan bir devlete yönelik olarak, belirli bir kesimin, bir grubun ya da genel halkin zihninde bir terör algısl yaratmak için plan ya da hesap yapmak gibi suç oluşturan tüm eylemler" (Ruperez, 2006) şeklinde değerlendirmektedir.

Terörizm kavramına yönelik resmî kurumlarca yapılan tanımlamaları baz alarak, izleyici kitlesini harekete geçirmeyi amaçlayan bir hükümeti, sivil nüfusu veya nüfusun herhangi bir bölümünü korkutmak veya sindirmek, siyasi veya sosyal amaçların yerine getirilmesini sağlamak için kişi veya mülklere karşı yasadışı güç veya şiddetin kullanılması şeklinde bir tanımlama yetersiz kalmakta ve kapsayıcı tanımlama sorununu çözememektedir. Her ne kadar böyle bir tanımlama Afganistan'da

\footnotetext{
${ }^{2}$ Jonathan White, Amerika birlikte Devletleri FBI Terörizm tanımı, Terrorism, Stamford: Wadsworth Thomas Learning, 2002.
} 
faaliyet gösteren Talibanı kapsıyor olsa dahi yalnızca Türkiye Taliban'1 terör örgütü olarak listelemektedir. ABD, İngiltere, NATO ve BM Afgan Talibanı'nı terör örgütü olarak kategorize etmemektedir. (Foreign Terrorist Organizatiions, 2020). Bu yüzden özellikle bu yap1 ve devletler tarafindan ortaya koyulan tanımlar örnekleme amacıyla seçilmiştir. Diğer taraftan Taliban gibi örgütlere ve üyelerine yardım eden kişilere ve devletlere kısıtlayıcı spesifik önlemler uygulanması kararı göz ardı edilmemelidir (Dowgielewicz, 2011).

\section{AFGANISTAN'DA TALİBAN ŞİDDETININ VE TERÖRÜNÜN ARKA PLANI}

Taliban, Pakistan hududu boyunca Deoband medreselerinde İslami eğitim alan ve bu eğitimi pratiğe geçiren öğrenci topluluklarından oluşmuştur. Bu öğrencilerin nihai amaçları da Afganistan'da şeriat ile yönetilen bir Afgan devleti tesis etmek ve böylece tüm Afgan toplumunu temizleyip arındırmaktır (Clements, 2003). Taliban'ın tarihsel olarak 19. yüzyılın ikinci yarısına tekabül eden kökleri 1857 yllında Hint Müslümanların İngiliz sömürgesinden ve otoritesinden kurtulmak için başlattıkları ayaklanmaya dayandırılabilir. İngilizlerin ayaklanmayı oldukça kanlı bir şekilde bastırmalarının ardından Müslüman âlimler Müslüman halkın daha kaliteli eğitim alabilmeleri için Hindistan'ın Deoband kentinde medrese ve ardından da Aligarh Müslüman Üniversitelerini kurarak duvar örgüsünün ilk taşını oluşturmuşlardır. Burada 1919 yılında kurulan "Cemiyet-i Ulema-i Hint" teşkilatı ile İngiliz sömürgesine karşı bir mücadeleye girişilmiş ve bu mücadele hem Pakistan’ı hem Afganistan'1 etkilemiştir. Pakistan'ın modern anlamda bir devlet olabilmesinde bu okulların katkısı oldukça büyüktür. Ancak Sovyetlerin Afganistan'1 işgal etmelerini takiben de bu okul Afganistan'da farklı bir hüviyet kazanmıştır. Pakistan'da Deoband medreseleri olarak isimlendirilen bu okullar Afgan alimleri oldukça etkilemiş ve Taliban'ın oluşumunda da büyük bir öneme sahip olmuştur (Saray, 2002). Afgan Talibanı'nı ortaya çıkartan birçok sebep bulunmaktadır. Bu sebepler burada iç ve dış faktörler olarak iki parçaya ayrılarak ele alınsa bile, ele alınanlar dışında birçok faktör bulunmaktadır.

İç faktörler dâhilinde Sovyetlerin ülkeden çekilmeleri, partiler arası çekişmeler, yolsuzluklar, yağmalar vs. önemli bir yer tutmaktadır. Daha açık bir şekilde ele almak gerekirse Sovyetlerin 1979'da başlayan Afganistan işgali 1989 yılı itibariyle sona ermiş ve Sovyetlerin çekilişlerini tamamlamaları ülkede otorite boşluğunu doğurmuş böylece partiler arasında büyük çatışmalar yaşanmıştır. Ülkenin birçok kentinde yaşanan çatışmaların yanı sıra Hizbi İslâmi partisi ve İttihad-ı İslâmi partisi arasındaki çatışmalarda yalnızca Koti Sengi'de 700 kişi hayatını kaybetmiştir. Afganistan'da otorite boşluğu sonucu devam eden çatışmalara dışarıdan bir yardım gelmezken, Pakistan açık bir şekilde Afganistan'daki ihtilafların daha da derinleşmesi için müdahalelerde bulunmuştur (Hassan, 2011). Diğer taraftan iç savaşların devam etmesi, merkezi otoritenin sağlanamaması, siyasi ve ekonomik çatışmalar, mücahit grupların birlik oluşturamamaları, oldukça fazla etnik köken barındıran devlet içerisinde milliyetçiliğin artış göstermesi, güç ögelerinin adaletsiz bir şekilde bölünmesi, güç bahşedilen kişilerin liyakat ve yeteneklerinin değerlendirilmemesi ve yetersiz kişilerin öne çıkması, hırsılzlı ve yağmanın olağan hale gelmesi, toplumda mal ve can güvenliğinin sağlanamaması, Afgan yerleşiklerinin 23 sene devam eden iç savaşlardan usanmış olmaları gibi nedenler Taliban'ın ortaya çıkmasında öne çıkan iç faktörler olmuştur (Beg, 2001).

Afganistan her ne kadar farklı etnik kökenlerden oluşsa bile ülkenin en büyük birlik noktasını İslami inanç oluşturmuştur ve Sovyet işgaline karşı da bu inançla direnen ve işgali takiben tesis edilen/edilemeyen hükümetlerin memnun edemediği, ülkenin etnik çoğunluğunu meydana getiren Peştunlar, Afgan Talibanı hüviyeti altında Afganistan'da etki göstermeye başlamışlardır (Beg, 2001); (Maley, 2002).

Dış faktörler bağlamında da yabancı devlet fonlamaları, silah ve militan desteği gösterilebilir. Birazcık daha açacak olursa Taliban'ın Afganistan içerisinde etkinlik kazanması dış mihrakların etkisi 
olmaksızın bu kadar keskin olamazdı ve Taliban'ın kaynaklara ulaşmak için ülke dışı faktörlere ihtiyacı vardı. Bu noktada Taliban ABD'nin yanında Pakistan ve Suudi Arabistan'dan da maddi ve askeri bakımdan ciddi bir destek görmüştür. Bu durumu en basit haliyle Benazir Bhutto Londra'da gerçekleştirilen bir basın toplantısında "Taliban, İngiltere'nin fikri, Suudi Arabistan'ın maddi desteği, Amerika'nın denetimi ve Pakistan'ın terbiyesiyle ortaya çıtı" (Aydın, 2010) şeklinde verdiği demeçle ortaya koymuştur. Bu ülkeler dışında Çeçenistan da milisler konusunda destek veren bir diğer ülke olmuştur (Abdullaev, 2002). ABD, Pakistan ve Suudi Arabistan ayrıca da Çeçenistan gibi aktörlerden alınan destek de dış faktörleri oluşturmaktadır.

\section{AFGAN TALİBANI'NIN ÖRGÜT YAPISI}

\section{Örgütün Önde Gelen İsimlerinden Bazları}

2001 yılında Amerika'nın Afganistan'ı işgali sonucu yıkılan Afganistan İslam Emirliği Liderleri tarafindan Pakistan'ın Quetta kentinde kurulan Quetta Şura örgütün liderlik yapısı olarak bilinmektedir (Muzul, 2009). Bu örgüt içerisindeki önemli isimlerden bazıları ise şu şekildedir:

Molla Muhammed Ömer (1994- 23 Nisan 2013): Taliban'ın kurucu lideri olan Molla Ömer öldüğü güne kadar örgütün liderliğini üstlenmiştir. 2013 tarihinde hayatını kaybeden Molla Ömer'in ölümü örgüt tarafından iki yıl gizli tutulmuş ve 2015 yılında açıklanmıştır (Profile: Mullah Mohammed Omar, 2015).

Abdul Ghani Baradar (1994- 8 Şubat 2010): Molla Muhammed Ömer'in vekili olan Baradar 2007'den 2010'a kadar Quetta Şura militan örgütünün liderliğini sürdürmüştür. Taliban'da 1lımlı bir lider olarak görülmüş, 2004 ve 2009 yılında barış görüşmelerine katılmıştır. Afgan Devlet Başkanı Hamid Karzai ile aynı Peştun kabilesinin üyesi olan Baradar'ın başına 2009 yılı başlarında Taliban'ın fiili lideri olduğu düşüncesiyle ABD 10 milyon dolarlık bir ödül koymuş ve 8 Şubat 2010 yılında da yakalamıştır (Moreau, 2009).

Molla Akhtar Muhammed Mansur (1996- 23 Mayıs 2016): Molla Mansur, Taliban'ın başkan yardımcısı ve Molla Ömer'in 2013'teki ölümü ile iki yıl sonra örgüt tarafindan Ömer'in ölümünün duyurulması arasındaki süreçte fiili lider olarak görev yapmıştır. Mansur, Afganistan'daki Taliban'ın nihai otorite olduğu dönemde Sivil Havacılık Bakanı olarak görev yapmış ve Temmuz 2015'te örgüt tarafından Taliban Baş Komutanı olarak ilan edilmiştir. Mayıs 2016'da Pakistan'daki bir ABD drone saldırısı sonucunda hayatını kaybetmiştir (Profile: Taliban Leader Mullah Akhtar Mansour, 2015).

Mevlevi Hibetullah Ahundzade (2015- ...): Bir din bilgini olan Mevlevi Hibetullah Ahundzade, Afganistan İslam Emirliği'nin eski yargı organı başıydı. Temmuz 2015'te Mansur'un Taliban Baş Komutanı olarak atanmasını takiben onun yerini almış (Shah \& Nordland, 2015) ve Mayıs 2016'da ABD'nin drone saldırısı sonucu Mansur'un ölmesiyle Taliban'ın emiri (lideri) olarak seçilmiştir (Profile: Taliban Leader Mullah Akhtar Mansour, 2015).

\section{Örgütün Kaynakları}

Taliban'ın kaynakları temel itibariyle Sovyet-Afgan savaşı sırasında mücahitlerin CIA programları kapsamında aldıkları desteğe dayanmaktadır (Fitchett, 2001). Başlarda mühimmat desteği emekli mücahitlerden sağlanmış olsa bile finansman kaynağının çoğu haşhaş üretimi ve uyuşturucu ticaretinden gelmekteydi. 1996-1999 yılları arasında Taliban, Afganistan'daki haşhaş tarlalarının \%96'sını kontrol ediyordu. ABD güçleri 2001 yılında Afganistan'ı işgal ettiklerinde bile haşhaş tohumu tarımı ve uyuşturucu ticareti Taliban'ın faaliyetlerinin \%60'lık bir bölümünden fazlasını finanse etmeye yetiyordu. (Chouvy, 2020) 2007 yılı ağustos ayında yayımlanan BM raporu Afganistan'ın dünyadaki eroinin \%93'ünü ürettiğini tahmin etmekteydi. NATO Koalisyon Güçlerinin ülkenin geniş bir kısmını 
ele geçirmesiyle Taliban'ın haşhaş üretimi ve uyuşturucu ticaretinden sağladığg fon \%40'lara düşmüş olsa bile 2018'den itibaren Taliban'ın bölgede büyük bir güç elde etmesiyle bu fon tekrardan yükselmiştir (Chouvy, 2020). Taliban'ın afyon gelirini yasadışı kereste ticareti, gasp ve kârlı madencilik operasyonlarıyla da desteklediği bilinmektedir (Dominguez, 2016). Bazı raporlar Taliban'ın yerel camilerden ve iş adamlarından da kötü zamanlarda bağış talep ettiğini göstermektedir (The Taliban Have Run Ouf Of Money Just As U.S. Troops Prepare To Leave Afghanistan, 2014). 2017'de Afganistan dünyada fistık üretiminde dokuzuncu sırada yer alırken 2017 itibariyle Taliban'ın fistık ağaçlarının yasadışı hasadından yılda 15 milyon dolar kazandığı belirtilmektedir (Walsch, 2017). Buna ek olarak, Taliban gruba katılmayı reddeden vatandaşlar üzerinde de ciddi vergilendirme yapmaktadır. 2017 yılında Taliban'ın elektrik faturaları, maaşlar ve ulaşımdan da ciddi bir gelir elde etmeye başladığının altı çizilmiştir (Gall, 2016). Son olarak Taliban, İslami yardım kuruluşlarından ve Afganistan dışındaki diğer kurumlardan ve ülkelerden de mali katkılar almaktadır. Bu katkıların çoğunluğu Pakistan ve diğer körfez ülkelerinden gelmektedir (Dominguez, 2016).

\section{ÖRGÜTÜN STRATEJÍSİ}

\section{İdeolojisi ve Amaçları}

Taliban'ın ideolojisi, 1980'lerde ve 1990'ların başlarında Sovyetlerle mücadele eden mücahitlerin geleneksel İslamcı görüşlerinden İslam'ın radikalleştirilmiş Deobandi -Deoband Medreselerinin öğretileri- yorumlarıyla harmanlanmış katı bir modernizm karşıtı Peştun aşiret ideolojisinin bir kombinasyonuna geçiş olarak kabul edilmektedir. Bununla birlikte Taliban, İslami şeriat kurallarının katı bir yorumuna ve uygulanmasına dönük ideolojik bir bağlılığa da sahiptir (Ahmed, 1996). Örgüt İslami cihadı "ilahi bir yükümlülük" olarak ifade etmektedir. Ayrıca cihadı desteklememenin büyük bir günah olduğunu belirterek üyeleri arasında cihadı teşvik etmektedir (Roggio \& Weiss, 2017). Bununla birlikte örgütün IŞSiD 'e karşı duruş sergilemesinin altında yatan nedenlerden birisi ise, IŞṠiD 'in aşırıcılığının Taliban'ın Batılı güçleri ülkeden kovmak amacıyla birleşik bir İslamcı hareket kurma hedefine yönelik tehdit unsuru olarak algılanmasına dayanmaktadır (Pollowitz, 2014).

\section{Siyasi Faaliyetleri}

1994 yılında ruhani liderleri Molla Ömer öncülüğünde kurulan Taliban 1996 y1lına gelindiğinde Afganistan İslam Emirliğini kurdu ve 9/11 saldırılarından sonra Usame Bin Ladin'in teslim edilmemesi üzerine ABD’nin ülkeyi işgal edip, hükümeti devirmesine kadar olan süre boyunca ülkeyi yönetti. Ancak Taliban tarafından kurulan Afganistan İslam Emirliği yalnızca Suudi Arabistan Pakistan ve Birleşik Arap Emirlikleri tarafindan tanındı (The Taliban, 2020).

Taliban 2001 yılında iktidardan sürüldüğünde, örgütün 1lımlı üyeleri, Taliban'ın barış süreçlerine katılması için baskı kurdu. Molla Ömer ise hayatı boyunca müzakerelere sürekli olarak karşı çıtıı ve siyasi muhaliflerin suikastlarını yönetti. 2015 yılında ölüm haberlerin duyurulmasından sonra, Taliban liderleri Afganistan'daki siyasi bir çözüm için ön müzakerelere karşı Molla Ömer'in katı tavrını takip etmedi, barış görüşmelerine ilgi gösterdi ve zaman zaman da bu görüşmelere dâhil oldu. Nihai kertede de 29 Şubat 2020 tarihinde ABD ve Taliban arasında Afganistan'a barış getirme antlaşması imzalandı (Khan, 2013); (ABD ve Taliban Anlaşma İmzaladı, Afganistan'daki Amerikan Askerleri 14 ay içinde çekilebilir", 2020).

\section{Örgütün Hedef Tahtası ve Hedeflere Yönelik Saldırı Yöntemleri}

Taliban'ın hedef tahtasının merkezinde Afgan hükümet güçleri ve koalisyon birlikleri yer almaktadır. Bununla birlikte hedef tahtasında yer alanlara yönelik; intihar saldırıları, geliştirilmiş infilak aygıtlarının konvansiyonel saldııları, roket saldırıları, suikastlar, gerilla savaşları, katliamlar, adam 
kaçırmalar yanı sıra sivillere ve sivil toplum kuruluşlarına yönelik saldırılar gerçekleştirilmektedir (Pape \& Feldman, 2010). 2009 yılında ABD kuvvetlerinin Afganistan'da varlıklarını arttırmaları da Taliban güçlerinin sivillere yönelik saldırılarını arttırmıştır. 2011 yılındaki Birleşmiş Milletler raporuna göre Taliban 2009 yılında sivil ölümlerinin \%76'llk ve 2011 y1lında da \%80'lik bir bölümünden sorumlu olarak tanımlanmıştır (Citing rising death toll, UN urges better protection of Afghan civilians, 2011).

ABD koalisyonunun Afganistan'1 işgalini takiben Taliban, halk toplanma noktalarına bombalar yerleştirmiş, halk pazarlarında suikast bombalamaları gerçekleştirmiş ve uluslararası güçleri hedef almak adına kadın suikast bombacıları kullanmıştır. Ayrıca Taliban'ın, sivilleri koalisyon güçlerini hedef bölgeye çekmek için kullandığı ve daha sonra yerleştirilen bombaları patlattıkları ya da bu güçlere yönelik intihar saldırıları gerçekleştirdiği ve gerçekleştirilen bu saldırılarda koalisyon güçlerinden ziyade daha çok sayıda sivilin hayatını kaybettiği bilinmektedir (Arnoldy, 2009).

29 Şubat tarihinde ABD ve Taliban arasında gerçekleştirilen Afganistan'a barışı getirme antlaşmasından sonra kimi yerlerde saldırılar azalmış olsa dahi Taliban hala Afgan güçlerini hedef almaya devam etmektedir. Ayrıca Covid-19 salgını için Taliban halk sağlığına yönelik kampanya başlattığını söylemiş ancak pozitif vakaların bildirildiği örgüt için kritik birçok Afgan bölgesine de 300'den fazla saldırı gerçekleştirmişti. Bununla birlikte İslam âlemi için mübarek olan Ramazan ayının 24 Nisan'da başlaması dolayısıyla ateşkes talep eden Afgan hükümetinin talebi de Taliban tarafindan reddedilmiştir (Marshal \& Rahim, 2020).

\section{Örgüt Tarafindan Gerçekleştirilen Önemli Saldırılardan Bazıları}

Ağustos 1994'te Taliban milisleri Maiwand'dan kuzeye doğru ilerlemiş ve Kandahar şehrini yaklaşık 30 militan kaybıyla ele geçirmişlerdir. Kısa süre sonra da Kandahar Taliban hükümetinin başkenti olmuştur (Afghan Taliban, 2018).

9 Eylül 2001 tarihinde gazeteci k1lığındaki iki El Kaide üyesi, Taliban’a karşı en büyük muhalefet olan Afgan sivil ve askeri lideri Ahmed Şah Mesud'a kameralarına gizlenmiş patlayıcılarla suikast düzenlemişler ve bu saldırı Taliban'ın Mesud'a karşı El Kaide ile hareket ettiği çıkarımlarını beraberinde getirmiştir (Afghan Taliban, 2018).

8 Eylül 2006 tarihinde, ABD’nin Kabil'deki büyük elçiliği dışında ABD zırhlı aracına bir intihar bombacısı arabasıyla çarpmış ve patlayıcıları patlatmıştı. Toplamda 16 kişinin hayatını kaybettiği 29 kişinin yaralandığı saldırıda ayrıca iki Amerikan askeri de saldırıda hayatını kaybetmişti. Bu saldırı 2001 Afganistan işgalinin başlamasından sonraki en kanlı ilk saldırı olmuştur (Afghan Taliban, 2018).

12 Temmuz 2011 tarihinde Afganistan Cumhurbaşkanı'nın üvey kardeşi ve Kandahar Valisi Ahmad Wali Karzai güvenlik şefi Sardar Mohammed tarafindan vurulmuş Taliban, saldırının sorumluluğunu üstlenerek saldırının 10 yıllık savaştaki en büyük başarılarından birisi olduğunu söylemiştir (Afghan Taliban, 2018).

11 Haziran 2013 tarihinde bir intihar bombacısı, Kâbil Yüksek Mahkemesi dışında, altı hâkimin yanı sıra birçok mahkeme çalışanını ve sivilleri de öldüren bir bombayı patlatmış ve 17 kişinin hayatını kaybetmiş 40'tan fazla kişi ise yaralanmıştı. Gerçekleştirilen saldırıyı Taliban üstlenmiş ve mahkeme çalışanlarının Afganlara karşı zalimce tavır takındıklarını ve kâfirlerin davranışlarını yasallaştırdıklarını söylemiştir (Afghan Taliban, 2018).

15 Eylül 2015 tarihinde Taliban militanları, 2001'de ABD'nin Afganistan'1 işgalinden bu yana Taliban'ın kat ettiği en büyük ilerlemeyi işaret eden Kunduz şehrini ele geçirmiştir. Saldırıda can kaybı olmamış, ancak şehrin kontrolünün Taliban'a geçmesi sağlamış ve 500 mahkûm Taliban tarafindan yerel hapishanelerden serbest bırakılmıştır (Afghan Taliban, 2018). 
20 Haziran 2018 tarihinde Taliban militanları Afgan askerlerine saldırmış ve Batı eyaleti Badghis 'de bulunan askeri üssü ele geçirmişlerdi. Bu saldırı bayram tatili için ateşkes çağrısından sonra gerçekleştirilen ilk büyük saldırı olmuş ve saldırıda en az 30 kişi hayatını kaybetmiştir (Ateşkes Sonrası Taliban'dan İlk Saldırı: 30 Ölü!, 2018).

04 Mart 2020 tarihinde Taliban'ın Kunduz'da gerçekleştirdiği saldırıda 16 Afgan askerinin hayatını kaybetmesi üzerine ABD müttefiki Afgan hükümetini korumak amacıyla Taliban'a yönelik ilk hava saldırısını gerçekleştirmiş ve Leggett, "Taliban liderleri, saldırılarını azaltmak için uluslararası topluma söz verdi. Taliban'ın sözünü tutmasını istiyoruz." şeklinde açıklama yapmıştır (Sadat, 2020).

\section{AFGAN TALIBANI'NIN KISA TARIHI: KURULUŞTAN AFGANISTAN'A BARIŞI GETIRME ANTLAŞMASINA}

1994 yılında ruhani liderleri Molla Muhammed Ömer önderliğinde İslamcı militan bir örgüt olarak ortaya çıkan Taliban taraftarlarının büyük bir çoğunluğu Afgan ve Pakistan medreselerinden gelen öğrencilerden oluşmakla birlikte, orijinal savaşçılarını 1979'dan 1989'a Sovyetlerle mücadele içerisinde olan mücahitler oluşturuyordu (Zachary, 2014). Taliban hareketinin hedefi Afganistan'da dini emirler doğrultusunda İslami sistem tesis etmekti. Bununla birlikte grubun doktrini de Emir'e yani lidere sıkı sıkıya itaat etmek ve molladaki sıkı güç yoğunluğuna odaklanmaktı (Semple, 2015).

1994 yılının 3 kasımında Taliban Kandahar kentinin kontrolünü sürpriz biz saldırıyla ele geçirdi ve bu saldırı sırasında yalnızca bir düzine adamını kaybetti. Bunun yanı sıra yolsuzluğu ve kanunsuzluğu önleyerek, yollar yaparak ve kontrolleri altındaki bölgelerde ticaretin güvenli bir şekilde yapılmasını sağlayarak hızlı bir şekilde popülaritesini arttırdı. Sonraki iki ay boyunca Taliban 12 vilayetin daha kontrolünü ele geçirdi ve Şubat 1995'e kadar militan sayısını 25 bine kadar yükseltti (Saikal, 2004). Bu gelişmelerin ardından Taliban, Pakistan'ın İstihbarat Teşkilatı (ISI)'den ciddi bir destek aldı. ISI, Talibanı, Pakistan için elverişli yeni bir iktidar gücü aşılamanın yanı sıra yeni bağımsız Orta Asya ülkelerine açık ticaret yollarının güvenliğini sağlama umuduyla Afgan hükümetine karşı saldırgan bir duruş oluşturmak için kullandı (Forsythe, 1999).

1996 yılına gelindiğinde Taliban Kabil'in kontrolünü başarıyla ele geçirdi ve Afganistan İslam Emirliği'ni oluşturdu. Molla Ömer devletin ilk başkanı oldu. Taliban yönetiminde, dünya çapında kadın ve çocuklara yönelik gelen eleştirilerin yanı sıra yetersiz hizmet alan vatandaşlara gıda ve yardım reddi konusunda da büyük eleştirilerin odağı olan katı Şeriat yasası yürürlüğe sokuldu ve Taliban yönetimi Şeriat kuralları ile yönetilen bir Afgan devleti kurma amacına ulaşmak için çeşitli geleneksel ve geleneksel olmayan savaş tekniklerini kullanmaktan imtina etmemişti (The Taliban, 2020). Ayrıca bu yıl içerisinde bir diğer terör örgütü olan El Kaide Sudan'dan Afganistan'a gelmişti. Ancak iki grup arasında ciddi gerilimler bulunmaktaydı. Bunlardan ilki etnik köken farklılığıydı. Taliban Afganlardan oluşuyor, El Kaide ise çoğunluklu Araplardan oluşuyordu. Bir diğer farklılık ise stratejik düşüncelerinde yatıyordu. El Kaide lideri Usame Bin Ladin başarıya ulaşmak için ABD ve diğer ülkelerde de faaliyet gösterilmesinin hayati olduğunu savunuyorken Molla Ömer bu görüşün tam karşısında yer almıştı (Kuehn \& Strick Van Linschoten, 2012).

1998 yılına değin Taliban ülkenin neredeyse \%90’lık bölümünü kontrol altına almayı başarmıştı. Bununla birlikte Taliban tarafindan yönetilen Afganistan, insan hakları ihlalleri ve El Kaide'nin lideri Usame Bin Ladin'i ve uluslararası alanda aranan diğer suçluları teslim etmeyi reddettiği için uluslararası alanda dışlanmıştı ve 1997-2001 yılları arasında yalnızca Pakistan, Suudi Arabistan ve Birleşik Arap Emirlikleri tarafından tanınıyordu. Diğer taraftan Ahmed Şah Mesud tarafından yönetilen Kuzey İttifak1 Birleşmiş Milletler 'deki konumunu korumakla birlikte, büyük ölçüde iki grup arasındaki muazzam etnik farklılıklardan dolayı Taliban hükümetinin ana askeri ve siyasi muhalefeti haline geldi; Taliban 
çoğunlukla Sünni Peştunlardan oluşurken, Kuzey İttifakında etnik Tacik ve Özbeklerden oluşmaktaydı. Hal böyle olunca gruplar arasındaki gerginlik de yükselmiş oldu (The Taliban, 2020).

7 Ağustos 1998 tarihinde Kenya ve Tanzanya'daki ABD büyükelçiliklerinin bombalanması üzerine ABD, El Kaide ağının bir parçası olduğuna inandığı Afganistan'daki bölgelere hava saldırısı düzenledi (McIntryre, 1998). Ancak Taliban, Usame Bin Ladin'in saldırılarda öldürülmediğini duyurdu. Bunun üzerine müzakere yoluyla Usame Bin Ladin'i teslim almak istediler ancak bir yıldan fazla bir zaman alan müzakere süreci sonuçsuz kaldı ve 19 Aralık 2000 tarihinde Birleşmiş Milletler tarafından Taliban hükümetine geniş çaplı yaptırımlar ve hava ambargosu uygulandı (Usama Bin Ladin: Pressing High Level Taliban Official Jalaluddin Haggani on Bin Ladin, 1999).

2001 yılına değin Afganistan'1 yöneten Taliban, 11 Eylül 2001 saldırılarının ardından Usame Bin Ladin'i teslim etmeyi reddettikten sonra ABD öncülüğündeki koalisyon güçleri Kuzey İttifak'ının da yardımıyla Afganistan'ı işgal etti ve rejimi devirdi (Zachary, 2014). Molla Ömer ve çoğu Taliban lideri yeni takipçiler edinmek ve yeniden toparlanmak için Pakistan sınırına kaçtılar. Böylece Quetta Şura'yı oluşturdular (The Taliban, 2020). Molla Ömer Pakistan'ın Belucistan bölgesindeki Quetta kentinde 2002 yılında ayaklanma gücü oluşturdu (Muzul, 2009). Hareket 2003 yılında genişletildi ve ağır Taliban desteğiyle büyümesini sürdürdü (Rowman \& Littlefield, 2014). Sonraki birkaç yıl boyunca da Afganistan ve Pakistan' da bulunan saklanma yerlerinde gizlendiler (Haddon, 2011). Bu arada 27 Kasım 2001'de Birleşmiş Milletler Almanya'nın Bonn kentinde Afganistan'da Taliban sonrası bir hükümet kurmak için Bonn Konferansını düzenledi. 14 gün süren konferansın ardından 5 Aralık 2001 tarihinde Bonn antlaşması imzalandı (Acet \& Doğan, 2017). Afganistan'ın dört bir yanından Afgan temsilcileri geçici bir yönetim tesis etmek için davet edildi. Ortaya çıkan güç paylaşımı antlaşması, öncelikle etnik olarak Tacik ve Özbek olan ve etnik olarak Peştun olan Talibanı dışlayan Kuzey İttifak üyelerini ayrıcalıklı kıldı. ABD, 2001 yılında Afganistan'daki bombalama kampanyasını sürdürerek Taliban'ın kendisini ortaya çıkartmasını engelledi ve Taliban karşııı bir grup olan Kuzey İttifakı kısa bir süre sonra da Kabil'e girebildi (Afghanistan Profile, Timeline, 2019). 25 Aralık 2003'te de yeni bir anayasa onaylandı ve 2014 yılının Ekim ayında Afganistan Cumhurbaşkanı Vekili Hamid Karzai seçildi (The Taliban, 2020).

Afganistan'da yeni bir anayasa onaylanmadan önce Mayıs 2003 y1lında ABD Savunma Bakanı Donald Rumsfeld Afganistan'daki büyük savaşın sona erdiğini açıkladı. Bunun üzerine NATO Uluslararası Güvenlik Yardım Gücü (ISAF) koalisyonunun sorumluluğunu kendi üzerine aldı. 2004 itibariyle de ABD Irak'taki savaşa konsantre olmuş ve dikkatini Afganistan' dan çekerek Irak'a vermişti. Bunu büyük bir firsat bilen Taliban intihar saldırılarını da içeren yeni taktikleriyle kendisini yeniden değerlendi. 2004 yılından önce Afganistan'da nadiren intihar bombalarına rastlanıyorken, 2004 yılında Taliban tarafından sadece intihar bombacılarıyla 6 adet saldırı gerçekleştirildi ve bu sayı 2005 ve 2006 yıllarında katlanarak büyük bir artış gösterdi (Ahmed, 1996); (The Taliban, 2020). Afganistan'da Taliban'ın saldırıların giderek artış göstermesi üzerine ABD'nin yanıtı Afganistan'a 4 bin 500 Amerikan askeri daha gönderilmesi oldu. Şubat 2009 yllında ise Obama yönetiminin iktidara gelmesiyle birlikte, Afganistan'a 17 bin Amerikan askeri daha gönderildi ve aynı yılın aralık ayına gelindiğinde Obama yönetimi 30 bin Amerikan askerinin daha Afganistan'a gönderilmesine karar verdi. Böylece Afganistan'daki Amerikan varlığı 100 bin askere ulaşmış oldu (The Taliban, 2020).

ABD'nin Irak'taki varlığının ani artışının aksine Afganistan'da yeniden toparlanan ve aktivitesini arttıran Taliban'a karşı ABD’nin varlığının ani artışının sonuçları çok daha karmaşık oldu. Gelen ek insan gücü Talibanı Kandahar kentindeki kalesinden ve Arghandab, Panwai ve Maiwand gibi çevre bölgelerden arındırmada oldukça başarılı oldu. Buna rağmen Taliban'ın operasyonları hala işlevseldi ve hala suikast düzenleyebiliyor, intihar saldırıları ihtiva edebiliyor ve hatta büyük hapishane kaçışlarını 
organize edebiliyordu. Ayrıca ülkedeki Amerikan varlı̆̆ını ani artışı Khost, Paktia ve Paktika gibi Afganistan'ın güneydoğu illerinde -ki bu bölgeler Taliban'ın Pakistan'daki güvenli bölgesine geçiş noktasıydı- daha az etkili olmuştur. Bölge ayrıca El Kaide ve Taliban bağlantılı bir örgüt olan Hakkani Ağ 1 -ki bu örgüt en tehlikeli ve etkili Taliban müttefiki olarak görülmekteydi- bakımından da büyük bir önem taşımıştır (Roggio \& Weiss, 2017).

Afganistan'da Talibanı barışa razı etmek amacıyla ilk gerçek girişim 2010 tarihinde Afgan Yüksek Barış Konseyi’nin tesis edilmesiydi. Bu konsey, politikacıları, sivil toplum aktivistlerini, eski mücahitler yanı sıra 1lımlı Taliban figürlerini de içeriyordu. Böylesi bir konsey oluşturmanın amacı isyancılarla barışı konuşabilmek için bir iletişim kanalı açmaktı. Taliban'a adres sağlayabilmek amacıyla da Katar Hükümeti Doha'da bir siyasi ofis açmayı kabul etti (Shafiqi, 2019). Ocak 2012 tarihinde de Taliban, ABD ile Afganistan'ın geleceği hakkında siyasi uzlaşma müzakerelerine başlamak üzere Katar'da kurulan ofiste Taliban tarafindan tutsak edilen ve son Amerikan savaş tutsağı olan Bowe Berghal'in üzerine yapılan görüşmeler için de bir enstrüman görevi gördü. Berghal'in serbest bırakılması karşıllı̆ında Taliban, Guantanamo Körfezi'nde tutulan daha sonraları grubun önemli komutanlarından birisi olacak olan Molla Mohammad Fazl'ın da dâhil olduğu 5 kişinin serbest bırakılmasını talep etti (Entous \& Barnes, 2014). Antlaşmaya rağmen ön görüşmelerden yalnızca iki ay sonra ABD'nin antlaşmaya uymadığı algısı nedeniyle ortak paydada buluşulamadı (U.S. War in Afghanistan , 2020). 2013 tarihinde de Doha'da Afganistan hükümeti ve Taliban arasında yapılmas1 planlanan görüşmelere Taliban'ın Afganistan İslam Emirliği yazılı bir tabela yanı sıra kendi bayrağını asmas1 sonucu Afgan hükümeti müzakerelerden çekilmiş ve Doha'da kurulan ofis müzakerelerin sonlanmasıyla kapanmış ve barış görüşmeleri de askıya alınmıştı (Sadat, ABD-Taliban barış görüşmelerine ara verildi, 2019).

Başkan Barack Obama 27 Mayıs 2014 tarihinde ABD kuvvetlerinin çoğunun 2016 sonuna kadar Afganistan'dan çekilmesini öngören bir takvim açıkladı. Açılanan takvimin ilk aşamasında, Afgan kuvvetlerinin eğitimi ve "El Kaide'nin kalıntılarına" karşı operasyonlar yürütmekle sınırlı olmakla birlikte, 2014 sonunda savaş misyonu bittikten sonra 9 bin 800 ABD askerinin bölgede kalmasını öngörüyordu (Sadat, ABD-Taliban barış görüşmelerine ara verildi, 2019). Ayrıca 2014 yılında 13 yıl boyunca Taliban' da liderlik yapmış olan Molla Abdul Qayyum Zaker ABD ve Taliban arasındaki barış görüşmelerinin devam edebileceği umuduyla istifa etti. 2015 Eylül'ünde Taliban 2001 yllındaki büyük yenilgisinden sonra üstünde kontrol sağlayabildiği ilk eyalet başkenti Kunduz'un kontrolünü ele geçirmeyi başardı (Who are the Taliban?, 2015). Bununla birlikte Talibanı ve örgütün devam eden başarısını ortadan kaldırmaya yönelik tüm ağır uluslararası ve ABD tarafından girişilen uğraşlara ve katılımlara rağmen Afgan Talibanı hiçbir zaman terörist bir örgüt olarak sınıflandırılmamış, atanmamış veya listelenmemiştir. Sadece silahlı direnişçi olarak değerlendirilmiştir (Kosnikas, 2015). Uluslararası toplum da giderek Talibanı Afganistan'ın geleceğinin bir parçası olarak görme eğilimindedir. 2015 yılının temmuz ayında Afgan Hükümet yetkilileri ve Taliban liderleri yeni barış sürecince birinci tur müzakereler için bir araya geldi (The Taliban, 2020). Ayrıca Rusya da IŞìD 'in Afganistan'da yayılmasını önlemek amacıyla Taliban'la iş birliğine gitti (ISIS: Russia Coordinating with Taliban Forces to Fight Terror Group, 2015).

Taliban Afgan hükümeti ile Temmuz 2015 y1lı müzakerelerinin ortasında, Molla Ömer'in ölümünü sürpriz bir şekilde duyurdu. Molla Mansur, Molla Ömer'in ölümü üzerine onun halefi seçildi. Molla Mansur'un ISI ile yakın ilişki içerisinde olduğu için Pakistan destekli müzakereleri desteklediğine inanılıyordu. Böylece Taliban'ın siyasi bürosu, Pakistan etkisinden kaçınmak için her ne antlaşma yapılacaksa Doha ofisinden yapılması gerektiği için müzakerelere karşı çıkıyordu (The Taliban, 2020). 
Bu karşı çıkan gruplardan birisinin lideri Molla Muhammed Resul, Molla Mansur'un liderliğini tanımayan bir hizip oluşturmuştu (Afghan Taliban Close Ranks around New Leader, 2016).

2016 Şubat'ının sonlarında Pakistan, Afganistan, ABD ve Çin, Kabil ile Taliban arasındaki müzakerelerle Afgan savaşını sona erdirmek için bir yol haritası üzerinde antlaşmaya vardılar. Taliban temsilcilerinin de 2016 ilkbaharında Pakistan'daki ilk barış müzakerelerinde Afgan yetkililerine katılmaları bekleniyordu, lakin 2016 mayısında ABD drone saldırısıyla Molla Mansur'u öldürünce Taliban iş birliği de bozulmuş oldu (Siddique, 2016). Güvenlik durumlarının kötüleşmesi bir kenara, Afgan güçleri Taliban'dan geniş toprakları geri almak için gerekli olan hem insan gücü hem altyapı hem de eğitimden yoksundu. Trump yönetimi de 2017'nin sonlarında ABD'nin büyük stratejisinin bir parçası olarak Afganistan'daki savaşı kazanmak, IŞíD'i yok etmek, El Kaide'yi ezmek ve Taliban'ın daha fazla güç elde etmesinin önüne geçmek için daha fazla birlik göndereceğini açıladı (Almukhtar, 2017).

2018 tarihi raporlarına göre Taliban tüm ülkenin \%4'lük bölümünün tamamen kontrolüne sahipken \%66'lık bölüm üzerinde de fiziki varlığını sürdürüyordu. Bununla birlikte Afgan hükümeti savaşı sonlandırmak adına ateşkes sağlamak ve resmi görüşmelere başlamak için hazır olduğunu dile getiriyordu (Sharifi \& Adamou , 2018). Afgan hükümetiyle görüşmeleri reddeden Taliban, Kabil hükümetinin gerçek bir gücünün olmadığını ve kukla bir yönetimden öteye gitmediğini bu yüzden onlarla masaya oturmayacaklarını eğer otururlarsa bu durumun Kabil hükümetine meşruiyet kazandıracağını söylüyordu (Qazi, 2019). Hal böyleyken de Afganistan'daki barış görüşmeleri için ABD ve Taliban Aralık 2018 tarihinde masaya oturmuşlardı. Ancak daha sonraları Amerikan askerlerine yönelik Taliban tarafından gerçekleştirilen bombalı saldırılar neticesinde görüşmeler askıya alınmıştı (Sadat, ABD-Taliban barış görüşmelerine ara verildi, 2019).

2019 yılında Taliban tarafindan gerçekleştirilen bombalı saldırılar sebebiyle defalarca ara verilen ABD-Taliban arası barış görüşmelerinde Aralık 2019 tarihinde sona gelindi ve Afgan hükümetinin katılımı olmaksızın Doha'da 28 Şubat 2020 tarihinde imzalanan Afganistan'a barışı getirme antlaşmasının imzalanmasıyla sonuçlandı (Afghan Conflict: Us and Taliban Sign Deal to End 18-year War, 2020). Şubat 2020'de imzalanan antlaşma hemen bir ateşkes öngörmemekle birlikte Afgan hükümeti ve Taliban arasında görüşmelerin antlaşmayı takip eden birkaç ay içerisinde gerçekleşeceğini belirtiyordu. Bu arada Afgan hükümet başkanı Gani, Afgan hükümeti koşullarına göre görüşmelere dâhil olacağını belirtiyordu (U.S. War in Afghanistan, 2020).

29 Şubat'ta ABD ve Taliban arasında imzalanan antlaşmanın diğer maddeleri ise şu şekildeydi:

- Antlaşmanın ilk 135 günü içinde ABD, Afganistan'daki kuvvetlerini 8.600'e indirecek ve müttefikler de güçlerini orantılı olarak azaltacak.

- Taliban ve Afgan hükümeti arasındaki görüşmelerin başlamasıyla 10 Mart'a kadar yaklaşık 5.000 Taliban mahkûmu ve 1.000 Afgan güvenlik gücü mahkûmu değiş tokuş edilecek.

- ABD ayrıca Taliban'a karşı yaptırımları kaldıracak ve gruba karşı ayrı yaptırımlarını kaldırmak için BM ile çalışacak.

- Taliban da ülke toprakları üzerinde El Kaide, IŞİD gibi yapılanmalara izin vermeyecek ve bunlara karşı mücadele edecek.

- Taliban, serbest bırakılan üyelerinin $\mathrm{ABD}$ ve müttefiklerine tehdit oluşturmamasını sağlayacak (U.S. War in Afghanistan, 2020).

ABD ve Taliban arasında Doha'da imzalanan antlaşma ABD'nin 18 yıldır Afganistan'da süren kanlı ve maliyetli savaşını sonlandırması anlamına geliyordu. $\mathrm{Bu}$ minvalde sorulması gereken 
sorulardan birisi bu antlaşmanın Afganistan'daki terörü dindirmekte ne denli katkı sağlayabileceğiyken bir diğeri ise ABD ve koalisyon güçlerinin çekildiği bir Afganistan'da sivil halka, özellikle kadın ve çocuklara yönelik insan hakları ihlallerine karşın önleyici bir gücün nasıl tesis edilebileceği sorusudur.

\section{GENEL DEĞERLENDİRME}

Afganistan tarihi süreç içerisinde sürekli olarak çatışmaların, savaşların ve işgallerin sürekli hüküm sürdügü bir ülke olarak var olmuştur. Bu süreçlerde her zaman olduğu gibi en yoğun acıları da yerel halk omuzlamak durumunda kalmıştır. Barındırdığı birçok etnik kökenin yanı sıra, zorlayıcı coğrafi yapısı ve ideolojik farklılıklar ve özellikle de dış etkenler ülkede istikrarlı bir yapının kurulamamasına sebep olmuştur. Ülkede artan yolsuzluklar ve 'kukla yönetimlerin' tesis edilmesi ülkede terörü ortaya çıkartan en büyük etkenlerden bir tanesi olmuştur. Ortaya çıkan terör örgütlerinden ülkeye en büyük zararı veren Afgan Talibanı; İslami Şeri hukuk kurallarının uygulandığı bir devlet kurma amacıyla Molla Muhammed 'in ruhani liderliğinde kurulmuş, 1996 yılında resmen varlığını ortaya koymuş ve 2001 yılına değin ülkede iktidarı sağlamıştır. 2001 yılından sonra, ABD öncülüğündeki koalisyonun ülkeyi işgal etmesi Taliban liderlerinin Pakistan sınırına kaçmalarına ve orada yeniden güç toplayarak Afganistan'da saldırılar gerçekleştirmesiyle zaman içerisinde ülkede yeniden iktidar alanı bulabilmelerine imkân sağlamıştır. ABD ve Taliban arasında da 2001'den bu yana süregelen 18 yıllık bir savaşta ABD finansal bağlamda trilyon dolarlara varan bir zarar görmüş bununla birlikte binlerce Amerikan askeri de hayatını kaybetmiştir. En nihayetinde de Taliban'la barış görüşmeleri için zemin hazırlama çalışmaları yapılmış ve birçok kez kesilen görüşmelere rağmen nihai kertede 29 Şubat 2020 tarihinde Afganistan'a barışı getirme antlaşması imzalanabilmiştir. Taliban ve ABD arasında gerçekleştirilen bu antlaşmanın Afganistan halkı lehine sonuçlanması pek de olası görülmemektedir. Bunun birçok sebebi bulunmaktadır. Sonuca götüren bir çatışma çözümü için çatışmanın altında yatan sosyal, politik ekonomik ve psikolojik etkenlerin net bir şekilde ortaya konulması ve çözümlenmesi gerekmektedir. Bu uğurda yalnızca ülkede varlığını sürdüren koalisyon güçlerinin çekilmesi Taliban'ın dış güçlerden arındırılmış bir Afganistan amacına hizmet edebilir gibi görülebilir ancak Taliban tam anlamıyla tüm Afganistan'a hâkim olsa bile Taliban terörü sonlanmayacaktır. Yalnızca yasal bir boyut kazanacaktır. Bununla birlikte gerçekleştirilen ABD ve Taliban arasındaki savaşı bitirmeye yönelik olan bu antlaşma neticesinde Afganistan'daki Amerikan askerleri ülkeye geri döneceklerdir. Kaldı ki ABD ve Taliban arasında imzalanan antlaşmadan hemen sonra dahi Afgan güçleri ve Taliban arasındaki çatışmalar sürmüş ve 2020 yılının ilk üç ayında 500'den fazla sivil hayatını kaybetmiştir (Afghan war killing civilians despite US-Taliban peace deal: UN, 2020). $\mathrm{Bu}$ antlaşmanın sonuçlarının Afganistan üzerine etkisinin olumsuz olarak görünmesindeki bir diğer neden Afgan hükümetinin görüşmelere katılmamış olmasıdır. Afgan hükümeti antlaşma sırasında taraf olmamıştır bu durum sürecin sekteye uğramasının yahut bölgede terörün daha da tırmanmasının en büyük olası etkenlerinden birisi olabilir. Ayrıca değinmek gerekir ki; Afganistan'da 1996'dan 2001 yılına değin iktidar olan Taliban yönetimi boyunca kadın ve çocuk hakları ciddi şekilde yok sayılmış ve şeriat kuralları gereğince çok katı cezalar ve yöntemler uygulanmıştır. 2001 yılında ABD koalisyonunun ülkeyi işgal etmesiyle halkın ABD’yi kurtarıcı olarak görmesine rağmen yıllarca süren savaş ülkedeki durumu çok daha istikrarsız bir hale getirmiştir. $\mathrm{Bu}$ antlaşmayla -elbette tam olarak planlandığ gibi sonuçlanacak olursa- $A B D$ ve koalisyon güçlerinin ülkeden çekilecek olması ülkeyi daha da karmaşık ve sorunlu bir hale getirecek ve Taliban terörünün, Afgan hükümetine ve halkına yönelik daha da artmasını muhtemel hala sokacaktır. ABD'nin bir nebze de olsa önleyici gücü tamamen ortadan kalkacak ve Taliban, Afgan hükümetini devirecek olursa tüm ülke nezdinde katı şeriat kurallarını gerçekleştirecek olan Taliban'ın eline geçecektir. Bu durum ülkedeki silahlı çatışmaları çözecek olsa bile insan haklarının ihlalini -özellikle de kadınlar ve çocuklar üzerindeki- oldukça arttırması muhtemeldir. Bununla birlikte ülke içerisinde Taliban'ın uygulayacağı baskıyla halk ve diğer güçler 
kontrol altına alınabilse bile, radikal İslamcı düşüncelere sahip böylesi bir örgütün daha da radikalleşerek, Afganistan sınırlarını da aşarak, El Kaide'nin gerçekleştirdiği gibi uluslararası toplum için bir tehdit haline gelebilmesi de muhtemeldir.

\section{KAYNAKÇA}

2656f-Annual country reports on terrorism. (2020). Erişim Adresi: https://uscode.house.gov/view.xhtml?path=/prelim@title22/chapter38\&edition=prelim. Erişim Tarihi: 28.03.2020

7215 TERÖRLE MÜCADELE KANUNU. (1991, Nisan 12). Erişim Adresi: https://www.mevzuat.gov.tr/MevzuatMetin/1.5.3713.pdf. Erişim Tarihi: 28.03.2020.

ABD ve Taliban Anlaşma Imzalad,, Afganistan'daki Amerikan Askerleri 14 ay içinde çekilebilir". (2020, Şubat 29). https://www.bbc.com. Erişim Adresi: https://www.bbc.com/turkce/haberler-dunya-51688527 Erişim Tarihi: 08.04.2020.

ABD, Taliban'la imzaladı̆̆ anlaşma kapsamında Afganistan'daki askerlerini çekmeye başladı. (2020, Mart 10). https://www.bbc.com. Erişim Adresi: https://www.bbc.com/turkce/haberler-dunya-51812263. Erişim Tarihi: 25.03 .2020 .

Abdullaev, N. (2002). Chechens Fighting with the Taliban: Fact or Propaganda? Jamestown Foundation Global Research and Analysis.

Acet, G. S., \& Doğan, F. (2017). 11 Eylül Olayları Sonrası ABD-Afganistan İlişkileri: İstiladan İşbirliğine. Sosyal Ekonomik Araştırmalar Dergisi, 64.

Afghan Conflict: Us and Taliban Sign Deal to End 18-year War. (2020, Şubat 29). https://www.bbc.com. Erişim Adresi: https://www.bbc.com/news/world-asia-51689443. Erişim Tarihi: 08.04.2020.

Afghan Taliban. (2018, Haziran). Erişim Adresi: https://cisac.fsi.stanford.edu/mappingmilitants/profiles/afghantaliban\#text_block_16833. Erişim Tarihi:27.04.2020.

Afghan Taliban Close Ranks around New Leader. (2016, Şubat 5). Erişim Adresi: https://english.alarabiya.net/en/News/gulf/2016/02/05/Afghan-Taliban-close-ranks-around-new-leader.html. Erişim Tarihi:08.04.2020.

Afghan war killing civilians despite US-Taliban peace deal: UN. (2020, Nisan 27). https://www.aljazeera.com. Erişim Adresi: https://www.aljazeera.com/news/2020/04/afghan-war-killing-civilians-taliban-peace-deal200427093342892.html. Erișim Tarihi: 27.04.2020.

Afghanistan Profile, Timeline. (2019). Erişim Adresi: https://www.bbc.com/news/world-south-asia-12024253. Erişim Tarihi:07.04.2020.

Ahmed, R. (1996). Taliban: Militant Islam, Oil, and Fundementalism in Central Asia. New Haven: Yale University Press.

Almukhtar, S. (2017, Ağustos 23). How Much of Afghanistan is Under Taliban Control After 16 Years of War with the U.S.? Erişim Adresi: https://www.nytimes.com/interactive/2017/08/23/world/asia/afghanistan-ustaliban-isis-control.html. Erişim Tarihi: 08.04.2020.

Arnoldy, B. (2009, Temmuz 31). In Afghanistan, Taliban kills more civilians than U.S. Erişim Adresi: https://www.csmonitor.com/World/Asia-South-Central/2009/0731/p06s15-wosc.html. Erişim Tarihi: 08.04.2020.

Ateşkes Sonrası Taliban'dan İlk Saldırı: 30 Ölü! (2018, Haziran 20). https://www.ntv.com.tr. Erişim Adresi: https://www.ntv.com.tr/dunya/ateskes-sonrasi-talibandan-ilk-saldiri-30olu,q6tD0JESYkue6S5Pbw6SUw. Erişim Tarihi: 27.04.2020.

Aydın, A. (2010). Afganistan'da Taliban Hareketinin Ortaya Çıkışı ve Mezhebi Görüşleri. Selçuk Üniversitesi Sosyal Bilimler Enstitüsü Yüksek Lisans Tezi. Konya: Selçuk Üniversitesi Sosyal Bilimler Enstitüsü .

Beg, R. (2001). Adl Afganistan'dı Taliban'ın eline nasıl düştü? . İstanbul: Turan Yayıncılık.

Chaliand, G., \& Blin, A. (2016). Zelotlar ve Haşhaşiler. G. Chaliand, \& A. Blin içinde, Terörizmin Tarihi Antikçağdan IŞiD'e (s. 65). İstanbul: Nora Kitap.

Chouvy, P.-A. (2020). "Opium: uncovering the politics of the poppy. Cambridge, Massachusetts: Harvard University Press.

Citing rising death toll, UN urges better protection of Afghan civilians. (2011, Mart 10). https://unama.unmissions.org: Erişim Adresi: https://unama.unmissions.org/citing-rising-death-toll-unurges-better-protection-afghan-civilians. Erişim Tarihi: 26.04.2020.

Clements, F. A. (2003). Conflict in Afghanistan: A Historical Encylopedia. California: ABCCLIO.

Dominguez, G. (2016, Ocak 21). How the Taliban Get Their Money. Deutsche Welle, Erişim Adresi: https://www.dw.com/en/how-the-taliban-get-their-money/a-18995315. Erişim Tarihi: 08.04.2020.

Dowgielewicz, M. (2011). COUNCIL DECISION 2011/487/CFSP. Official Journal of the European Union . 
Entous, A., \& Barnes, J. E. (2014). Behind Bowe Bergdahl's Release a Secret Deal That Took Three Years. The Wall Street Journal.

Fitchett, J. (2001, Ekim 26). What About the Taliban's Stinger? Nytimes.com Erişim Adresi: https://www.nytimes.com/2001/09/26/news/what-about-the-talibans-stingers.html. Erişim Tarihi: 08.04.2020.

Foreign Terrorist Organizatiions. (2020, Nisan 08). www.state.gov: Erişim Adresi: https://www.state.gov/foreign-terrorist-organizations/. Erişim Tarihi: 28.03.2020.

Forsythe, D. (1999). Encylopedia of human rights . Oxford University Press, 2.

Gall, C. (2016, Aralık 06). Saudis Bankroll Taliban, Even as King Officially Supports Afghan Government. nytimes.com, Erişim Adresi: www.nytimes.com/2016/12/06/world/asia/saudiarabia-afghanistan.html. Erişim Tarihi: 08.04.2020.

(2019). Global Terrorism Index 2019 Measuring The Impact of Terrorism. Sydney: Institute for Economic \& Peace.

Haddon, K. (2011). Afghanistan Marks 10 Years since War Started. Yahoo News.

Hassan, S. M. (2011, Haziran 14). Afganistan Savaşı'nin Pakistan Siyasetine Etkileri (The Effects of Afghan War on Politics of Pakistan). Erişim Adresi: https://www.bisav.org.tr/Bulten/116/880/afganistan_savasi_nin_pakistan_siyasetine_etkileri_the_effects of_afghan_war_on_politics_of_pakistan. Erişim Tarihi: 28.04.2020.

ISIS: Russia Coordinating with Taliban Forces to Fight Terror Group. (2015, Aralık 24). www.ibtimes.com. Erişim Adresi: https://www.ibtimes.co.uk/isis-russia-coordinating-taliban-forces-fight-terror-group1534774. Erişim Tarihi: 08.04.2020.

Khan, T. (2013, Mart 04). War-weariness?: Taliban May Launch Political Party. theexpresetribune.com. Erişim Adresi: https://tribune.com.pk/story/515514/war-weariness-taliban-may-launch-political-party/?amp=1. Erișim Tarihi: 08.04.2020.

Kosnikas, I. (2015, Şubat 19). Call the Taliban What They are- Terrorists. www.foreignpolicy.com. Erişim Adresi:https://foreignpolicy.com/2015/02/19/call-the-taliban-what-they-are-terrorists/. Erişim Tarihi: 08.04.2020.

Kuehn, F., \& Strick Van Linschoten, P. (2012). The Enemy We Created: The Myth of the Taliban- AlQaeda Merger in Afghanistan. Oxford University Press.

Maley, W. (2002). The Afghanistan Wars. Palgrave Macmillan, 225.

Marshal, M., \& Rahim, N. (2020, Mart 28). Taliban Attack Afghanistan Amid Growing Coronavirus Threat. www.nytimes.com. Erişim Adresi: https://www.nytimes.com/2020/03/28/world/asia/taliban-afghanistancoronavirus.html. Erişim Tarihi: 26.04.2020.

Martin, G. (2017). Terörizm Kavramlar ve Kuramlar. Ankara: Adres Yayınları.

McIntryre, J. (1998, Ağustos 21). U.S. Missiles Pound Targets in Afghanistan, Sudan. www.cnn.com. Erişim Adresi: http://edition.cnn.com/US/9808/20/us.strikes.02/. Erișim Tarihi: 27.04.2020.

Moreau, R. (2009, Temmuz 25). America's New Nightmare. realclearpolitics.com. Erişim Adresi: https://www.realclearpolitics.com/2009/07/26/america039s_new_taliban_nightmare_218449.html. Erişim Tarihi: 08.04.2020.

Muzul, J. (2009). The Quetta Shura Taliban: An Overlooked Problem. International Relations Review.

(2019). NATO Glossary of Terms and Definions (English and French). NATO.

Öktem, E. (2004). ULUSLARARASI HUKUKTA TERÖRIZM Tanım sorunu ve milli bağımsızlık hareketleri. Istanbul Ticaret Üniversitesi Dergisi, 133-147.

Pape, R. A., \& Feldman, J. K. (2010). The Explotion of Global Suicide Terrorism and How to Stop. University of Chicago Press, 142.

Pollowitz, G. (2014, Aralık 31). The Taliban Warns ISIS of Being Too Extreme. www.nationalreview.com. Erişim Adresi: www.nationalreview.com/the-feed/taliban-warns-isis-being-too-extreme-greg-pollowitz/. Erişim Tarihi: 27.04 .2020 .

Profile: Mullah Mohammed Omar. (2015, Temmuz 29). https://www.bbc.com/. Erişim Adresi: https://www.bbc.com/news/world-south-asia-13501233. Erişim Tarihi: 08.04.2020.

Profile: Taliban Leader Mullah Akhtar Mansour. (2015, Ekim 30). bbc.com. Erişim Adresi: https://www.bbc.com/news/world-asia-34405035. Erişim Tarihi: 08.04.2020.

Proscribed Terrorist Organisations. (2020, Şubat 2020). Erişim Adresi: https://assets.publishing.service.gov.uk/government/uploads/system/uploads/attachment_data/file/869496 /20200228 Proscription.pdf. Erișim Tarihi: 26.04.2020.

Qazi, S. (2019, Ağustos 13). 'Peace deal is near': What we know so far about US-Taliban talks. www.aljazeera.com. Erişim Adresi: https://www.aljazeera.com/news/2019/05/taliban-talks-peaceafghanistan-190510062940394.html. Erişim Tarihi: 08.04.2020. 
Roggio, B., \& Weiss, C. (2017). Taliban Promotes 4 Previously Unidentified Training Camps in Afghanistan. FDD's Long War Journal.

Rowman, \& Littlefield. (2014). The World Almanac of Islamism. American Foreign Policy Council.

Ruperez, J. (2006, 01 26). THE UNITED NATIONS IN THE FIGHT AGAINST TERRORISM. Erişim Adresi: https://www.un.org/sc/ctc/wp-content/uploads/2017/01/2006_01_26_cted_lecture.pdf. Erişim Tarihi: 28.03.2020.

Sadat, K. (2019, Aralık 13). ABD-Taliban barış görüşmelerine ara verildi. aa.com.tr. Erişim Adresi: https://www.aa.com.tr/tr/dunya/abd-taliban-baris-gorusmelerine-ara-verildi/1673058. Erişim Tarihi: 08.04.2020.

Sadat, K. (2020, Mart 04). Afganistan'daki ABD güçlerinden Taliban ile anlaşma sonrası ilk hava saldırısı. www.aa.com.tr. Erişim Adresi: https://www.aa.com.tr/tr/dunya/afganistandaki-abd-guclerinden-talibanile-anlasma-sonrasi-ilk-hava-saldirisi/1754507. Erişim Tarihi: 27.04.2020.

Saikal, A. (2004). Modern Afghanistan: A history of Struggle and Survival. I.B. Tauris.

Saray, M. (2002). Afganistan ve Türkler. Avrasya Stratejik Araştırmalar Merkezi, 1.

Semple, M. (2015, Ocak 5). Rhetoric, Ideology and Organizational Structure of the Taliban Movement. www.usip.org. Erişim Adresi: https:/www.usip.org/publications/2015/01/rhetoric-ideology-andorganizational-structure-taliban-movement. Erişim Tarihi: 07.04.2020.

Shafiqi, H. (2019, Şubat 29). Afghanistan: The Long Road to Peace. bbc.com. Erişim Adresi: https://www.bbc.com/news/world-asia-51674103. Erişim Tarihi: 08.04.2020.

Shah, T., \& Nordland, R. (2015, Temmuz 31). Taliban Pick New Chief and 2 Hard-Line Deputies. nytimes.com. Erişim Adresi: https://www.nytimes.com/2015/08/01/world/asia/taliban-leader-announcement.html. Erişim Tarihi: 08.04.2020.

Sharifi, S., \& Adamou , L. (2018, Ocak 31). Taliban Threaten 70\% of Afghanistan, BBC Finds. bbc.com. Erişim Adresi: www.bbc.com/news/world-asia-42863116. Erişim Tarihi: 08.04.2020.

Siddique, A. (2016, Mart 02). Aziz Admits Pakistan Housing Afghan Taliban Leaders. https://www.dawn.com. Erişim Adresi:https://www.dawn.com/news/1243093. Erişim Tarihi: 08.04.2020.

The Taliban. (2020). Erişim Adresi: https://www.cfr.org/interactives/taliban?cid=marketing_usetaliban_infoguide-012115\#!/taliban?cid=marketing_use-taliban_infoguide-012115. Erişim Tarihi: 07.04.2020.

The Taliban Have Run Ouf Of Money Just As U.S. Troops Prepare To Leave Afghanistan. (2014, Şubat 3). ibtimes.com. Erişim Adresi: https://www.ibtimes.com/taliban-have-run-out-money-just-us-troops-prepareleave-afghanistan-1552964. Erişim Tarihi: 08.04.2020.

U.S. War in Afghanistan . (2020). Erişim Adresi: https://www.cfr.org/timeline/us-war-afghanistan. Erişim Tarihi: 08.04.2020.

Usama Bin Ladin: Pressing High Level Taliban Official Jalaluddin Haggani on Bin Ladin. (1999, May1s 24). Erişim Adresi: https://nsarchive2.gwu.edu/NSAEBB/NSAEBB389/. Erişim Tarihi: 07.04.2020.

Walsch, J. (2017, Mart 14). Funding Terrorism: Taliban Earns \$15M A Year From Pistachios In Afghanistan. ibtimes.com. Erişim Adresi: https://www.ibtimes.com/funding-terrorism-taliban-earns-15m-yearpistachios-afghanistan-2508055. Erişim Tarihi: 08.04.2020.

Who are the Taliban? (2015, Ekim 29). www.bbc.com. Erişim Adresi: https://www.bbc.com/news/world-southasia-11451718. Erişim Tarihi: 08.04.2020.

Zachary, L. (2014, Haziran 4). The Taliban in Afghanistan. Erişim Adresi: https://www.cfr.org/backgrounder/taliban-afghanistan. Erişim Tarihi: 07.04.2020. 


\section{EXTENDED ABSTRACT}

Terrorism fact is not only belong to our time, but also it belongs to the past. First reflections of the terrorism date back to Jewish Zealots and Hassan Bin Sabbah's Assassins (Chaliand \& Blin, 2016). From those days to the present time, states, preceptions, expressions and societies have changed. However, terrorism fact is still exist. On the other hand, the acceptance of terrorism and the terrorist acts are more complex than before. The main reason of it is about the assestment.

In this article, Taliban organisation, one of the non-state armed actors in Afghanistan is analyzed. There are two main reasons for analyzing this organisation. One of the reason shows itself in the statistics which was revealed by Global Terrorism Index (Global Terrorism Index 2019, Measuring The Impact of Terrorism) which shows how Taliban's terrorism affected the Afghanistan sociologically and economicly. The other reason is about the assestment. In the beginning of the paraghraph, it was said as non-state armed actors instead of terrorist organisation even if the actions of the organisation go parallel with the concept of terrorism. This assestment is not accepted by Turkey but USA, UK, UN and NATO. Those states and the unities consider Taliban as armed rebels not as terrorist organisation. And this is really important point. Because such assestment allowed United States to consider the chance of searching a way to the conflict resolution such as establishing the peace with an agreement. In this perspective, in the late of February, 2020, USA and Taliban signed an agreement after more than 18 years of conflict which is called "the agreement for bringing peace" to Afghanistan. In the first sight, this agreement might be seen as a constructive progress. But there are really important concerns about this agreement. And those significant concerns are construct the research question. One of the worrisome concern about this matter is, will this agreement come to an end the conflict? More importantly, when US leaved the Afghanistan who will be there to protect human rights especially for women and children?

For understanding the assestments and the concerns, primarily, the concept of terrorism and how the spesific countries consider the concept were analysed. After that, it was researched what was the main reasons to show up the Taliban's violence and terrorism in Afghanistan. In the following part, the main informations about the organisation was shared such as the structure of the organisation, resources of the organisation, strategies of the organisation, target board, type of attacks, and lastly the main attacks of the organisation and the concequences. After those informations, from the establishing the organisation to the peace agreement; Taliban's history, how the parties come together to sign the agreement was inspected. Finally, it was discussed how much this agreement will be affective, how Afghan people will be affected, how this agreement cause the absence of human rights, why leaving the rule of Afghanistan to Taliban might cause the threat to international security.

\section{The Concept of Terrorism}

The concept of terrorism is based from the word "terror" which means the extreme fear and anxiety from the unseen and unknown threat (Öktem, 2004). But academicians, specialists and the institutions discussed the word differently. Therefore, there is no consensus on describing the concept. However, UK describes the concept in Prevention of Terrorism Act 2005 (Prevention of Terrorism Act, 2005) report, USA describes the concept in Patterns of Global Terrorism Report 2003 (2656f - Annual country reports on terrorism., 2003). Even if, these both countries describe the concept as close as each other's, they identify Taliban as armed rebels not as terrorist organisations. On the other hand, Turkey describes the terrorism in Fight Against Terrorism Law No. 7215 in 2003, and identifies Taliban as a terrorist organisation. These mainly shows the political assestment determine the acceptence of the concepts.

\section{The Background of Taliban's Violence \& Terrorism}

The background of Taliban's violence and terrorism had been determined by internal and external factors. As internal factors, the withdrawal of the Soviets from Afghanistan, the disagreements between the parties, corruption and pillages had been the determinants of internal factors. On the other hand, funds from foreign countries, millitants and arm supports had been the determinants of external factors. 


\section{The Structure of Taliban Organisation}

Quetta Shura, which was established in Quetta, Pakistan by the leaders of the Islamic Emirate of Afghanistan, which was destroyed as a result of the American invasion of Afghanistan in 2001, is known as the leadership structure of the organization (Muzul, 2009)

\section{The Resources of the Organisation}

There are couple of main resources of the organisation. Taliban resources are mainly based on the support the mujahideen received under CIA programs during the Soviet-Afghan war (Fitchett, 2001). Even if the main resources were based on the support the mujahideen, another main financial resource had been coming from drug traffic (Chouvy, 2020).

\section{Strategies of the Organisation}

The Taliban has an ideological commitment to strict interpretation and application of Islamic Sharia rules. The organization expresses Islamic jihad as "a divine obligation". Organisation also promotes jihad among its members by stating that it is a great sin not to support jihad (Roggio \& Weiss, 2017).

\section{Target Board of the Organisation and Attack Methods Against Targets}

Afghan government forces and coalition troops had been at the center of the Taliban's target board. However, for those on the target board; Suicide attacks, conventional attacks of advanced explosion devices, rocket attacks, assassinations, guerrilla wars, massacres, kidnappings, as well as attacks against civilians and nongovernmental organizations had been carried out (Pape \& Feldman, 2010).

\section{Some of the Major Attacks}

In August 1994, Taliban militias advanced north from Maiwand and captured the city of Kandahar with the loss of about 30 militants. Kandahar soon became the capital of the Taliban government.

On September 9, 2001, two Al-Qaeda members disguised as journalists and assassinated the biggest opposition to the Taliban, the leader of Afghan civilian and military, Ahmad Shah Masud, with explosives hidden in their cameras. In addition, this attack showed that the Taliban are working with Al Qaeda.

\section{Afghanistan}

Short History of Afghan Taliban: From the Foundation to the Agreement for Bringing Peace to

The Taliban, which emerged as an Islamist militant organization under the leadership of their spiritual leader Mullah Mohammad Omar in 1994, consisted of students from Afghan and Pakistani madrasas, but their original fighters were mujahids who were fighting the Soviets from 1979 to 1989 (Zachary, 2014). Taliban seized control of Kandahar city with surprise attack on 3 November 1994. By 1996, the Taliban successfully took control of Kabul and formed the Islamic Emirate of Afghanistan. Mullah Omar became the first president of the state. Until 1998, the Taliban had been controlling almost $90 \%$ of the country. After the bombing of the US embassies in Kenya and Tanzania on August 7, 1998, the US carried out an airstrike on areas in Afghanistan that it believed were part of the Al Qaeda network. US wanted to capture Osama Bin Laden by negotiation, but the negotiation process, which took more than a year, and result was zero. US-led coalition forces invaded Afghanistan and overthrew the regime with the help of the Northern Alliance in 2001. Mullah Omar and most Taliban leaders fled to the Pakistani border to recruit new followers and regroup. Therefore, they created the Quetta Shura. After a couple of years, Taliban started new attack raids to Afghanistan. In the following years, US sent more troops to the Afghanistan and conflict increased. New paths were researched and for the resolution of the conflict, a couple of meeting organized, and finally in the late of February 2020, "Agreement for Bringing Peace to Afghanistan" is signed.

\section{Overall Assessment}

It seems unlikely that this agreement between the Taliban and the USA will result in favor of the people of Afghanistan. There are many reasons for this. Social, political, economic and psychological factors underlying the conflict should be clearly identified and resolved for a conflict resolution that leads to a result. For this reason, it 
can be seen that the withdrawal of only the coalition forces that exist in the country can serve the Taliban's goal of an Afghanistan free from foreign powers, but even if the Taliban fully dominates Afghanistan, the Taliban terror will not end. It will only take a legal dimension. However, even if the people and other forces can be brought under control by the pressure of the Taliban in the country, it is also possible that such an organization with radical Islamist ideas will become even more radical and become a threat to the international community, as al-Qaeda did. 